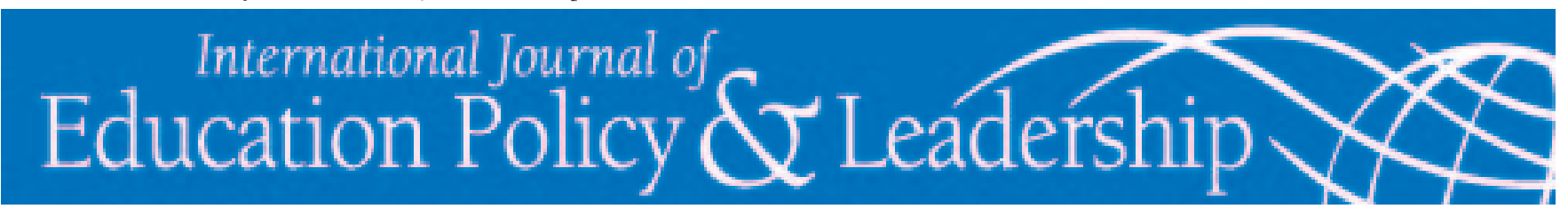

\title{
Africentric Education Leadership: TheOry ANd Practice
}

\author{
KMT G. SHOCKLEY \\ George Mason University
}

\begin{abstract}
This article unveils the largely unknown theories and practices of "cultural reattachment Africentric education leaders," because many people of African descent are now choosing to reattach (in whole or in part) to aspects of certain African cultures (such as Wolof or Akan). The article offers a brief background of African-centered education, discusses the theories and philosophies of Africentric education leaders, and explicates the methodology of this Africentric research project. Africentric education leaders are concerned about black communities becoming more avaricious but less unified; therefore, they offer African cultural ethos to combat both miseducation and individualism. This article also provides policy recommendations for instituting Africentric education as a comprehensive approach to address myriad problems being faced by black children and communities. In this research I advocate for Africentric theory and also employ ethnographic methods as I examine Africentric education practice.
\end{abstract}

Shockley, K. G. (2008). Africentric education leadership: Theory and practice. International Journal of Education Policy and Leadership 3(3). Retrieved [DATE] from http://www.ijepl.org.

\section{Introduction}

The inability of the American educational system to properly address the cultural and educational needs of blacks is one of the most perplexing problems in U.S. society today. Even as the population of blacks and other groups has continued to increase, many scholars have reported that the culture of schools has remained ethnocentrically white (Delpit, 2001; King, 2005; Stedman, 1997; Tharp \& Gallimore, 1991). For example, according to the National Center for Education Statistics (NCES, 2004), from 1986 to 2001 the population of blacks, first-language Spanish speakers, and Asians enrolled in U.S. public schools grew from 29.7 percent to 39.5 percent. However, the teaching force remained overwhelmingly white and female, and the academic achievement gap between whites and other groups (such as blacks and Latinos) persisted. Furthermore, black students represented 17 percent of the total U.S. public school population, yet they represented 36 percent of the students suspended from school and 32 percent of the students expelled from school (Anderson, 2005). Also, black students had lower math and reading scores than all other cultural groups (NCES, 2004). As Lomotey (1992) explained, "the academic achievement of a large number of black children across the country-as measured by standardized achievement tests, suspension rates, special education placement rates, and dropoutrates has deteriorated considerably over the last 20 years" (p. 455). Education scholars and practitioners work to figure out how to address the problems that black children face in U.S. public schools.

A growing group of black scholars and practitioners called "cultural reattachment Africentric educators" believes that black students need an African culturebased education that is focused on their particular learning needs. This article unveils and explores the theories and practices of the leadership of cultural reattachment Africentric ${ }^{l}$ educators. Cultural reattachment is a process whereby people of African descent begin to adopt aspects of an African culture (such as Wolof or Akan) as part of their daily practices. In this article, I define African-centered education as a process of reconnecting African children (and communities) with indigenous African cultural ethos. Reattachment also involves accepting the notion that Africans have the ability and

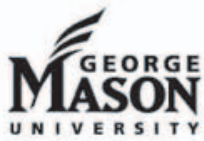


entitlement to "control the psychic and physical spaces that [people of African descent] call their own" (Akoto, 1992, p. 3). The approach primarily involves becoming intricately familiar with indigenous African cultures, accepting or practicing an African culture, and using the culture to inform the education of children of African descent. Proponents of cultural reattachment Africentric education advance important concepts, ideas, and practices for black children and communities, and I explore many of those in this article. It is important to note that many Africentric school-based practitioners write literature that is used by thousands of classroom teachers and researchers (e.g., Akoto, 1992; Akoto \& Akoto, 1999; Anwisye, 2006; Madhubuti, 1973, 1978, 1990; Rivers, 1998, 1999, 2000, 2001; Thompson, 1994, 1998).

\section{Purpose of the Study}

Africentric educationists receive less mainstream public attention and fewer acceptances of their work in major outlets such as mainstream journals. Yet they continue to inconspicuously influence the dialogue related to educating black children through outlets beyond the mainstream and through their constant appearances on the lecture circuit in black communities (e.g., Na'im Akbar, Jawanza Kunjufu, Mwalimu Shujaa, Asa Hilliard, Marimba Ani, Julia Hare). Africentric education leaders may have some very important solutions for the recurring problems being faced by black children. Therefore, the purposes of this study are threefold: (1) to understand Africentric education leaders' rationales for using Africentric ideas to educate black children and communities, (2) to explore the background, practices, some of the literature, and the theoretical framework of cultural reattachment Africentric education, and (3) to explore what policy-related changes may be necessary to improve the educational conditions under which black children now exist. Africentric education is becoming more popular among African Americans because other proposals are not strong enough to bring about the necessary changes to create a new reality for black children (Asante, 1991, 1998; Hilliard, 2003; Murrell, 2002). By unveiling the practices, theories, and philosophies of Africentric education leaders, this study offers policymakers and the like more options in their quests to provide an adequate and meaningful education to all children.

\section{Background}

African-centered education involves the act of making the education that black children receive relevant and meaningful to the black community. In order to do so, it is necessary for those who teach black children to assume the task of conducting careful historical and cultural studies of Africans (Asante, 1990). From an Africentric perspective, historical and cultural studies of blacks require deep engagement with African history and culture because blacks' roots are in Africa. Therefore, in order to more fully grasp the history of black education and anything that is related to blacks, the African roots must first be understood (Akoto, 1992; Akoto \& Akoto, 1999; Asante, 1990; Hilliard, 1997; Shujaa, 1994). After the periods of American chattel slavery and educational segregation, there was an inadequate review of the effects such events had on blacks as human beings. No major investigations of black children's learning styles were conducted. Instead, after educational segregation blacks were (and still are) expected to perform in school as if understanding who they are as learners is a moot point (Anwisye, 2006; Hale-Benson, 1982; Hilliard, 1997). A result of such negligence is that black children continue to suffer in U.S. public schools.

Educators sometimes question how groups such as Asians can perform well in U.S. schools without Asiancentered education. Africentric educationists explain that comparing blacks to Asians and other "voluntary minorities"-people who chose to come to the United States (Ogbu, 1993)_offers only an incomplete analysis of the situation. Blacks are "involuntary minorities" because they were forced to come to the United States (Ogbu, 1993) and were subjected to laws, codes, and treatment to which no other group has ever been subjected (Anderson, 1994, 2001). Africentric educationists call the educational system "Eurocentric," meaning that the system has the tendency to be sufficiently concerned with the intellectual and communal forward progress of only the majority population. Africentricity is "both a corrective and a critique of this European hegemony" (Asante, 1988, p. 8). Africentric educationists do not wish to replace one hegemonic system with another, but instead wish to replace a system that is insufficient for children of African descent with one that is culturally relevant.

Although it is generally agreed on that Molefi Asante (1980) coined the term "Afrocentricity" in its modern vernacular, the movement toward African centeredness began decades before, when Carter G. Woodson clarified that the education blacks were subjected to in U.S. schools was, in fact, not education at all, but rather "miseducation." Woodson (1933) explained that African Americans "have an attitude of contempt toward their 
own people because in their own as well as their mixed schools, they are taught to admire the Hebrew, Greek and Latin, and taught to despise the African" (p. 1). Woodson declared that blacks need an education that places them at the core of their own learning. The leadership of African-centered schools has attempted to create spaces where blacks appear at the core of their educational experience.

In the late 1980s, Afrocentric education gained popularity and Afrocentric schools experienced rapid growth through the early 1990s. African American parents had much faith in the "new" approaches for teaching and reaching black children (Akoto, 1992; Akoto \& Akoto, 1999). But in the mid-1990s Afrocentric education and Afrocentric ideas came under fire in the United States. Critics claimed it disunited America and presented pseudo-history to students (Schlesinger, 1992). Others claimed that Afrocentrism was an excuse to teach myths as facts (Lefkowitz, 1996). Still others said that Afrocentric ideas engendered a false consciousness in blacks because proponents irresponsibly created "mythical pasts and imagined homes" for blacks (Howe, 1998). Others contended that Africentric ideas were overly simplistic attempts to romanticize African history (Appiah, 1993). In many ways, this relatively comprehensive approach to addressing the myriad problems being faced by black children and communities has been politicized out of mainstream discussions, largely by scholars who are not even in the field of education.

\section{Theory and Practice: The Africentric Framework}

Africentric ideas require a reorientation of thinking on issues pertaining to education because when traditional lenses are used, they are often insufficient tools for understanding black phenomena (Asante, 1990). For example, Africentric educationists argue that although multicultural education may be useful, in its current form it compromises the black community's need to regain some basic security such as the formulation of a sense of African identity. Multiculturalism was explicated by Banks (2001) as a reform effort involving six major changes or additions to the standard curriculum (e.g., Banks called for an equity pedagogy). But nowhere in Banks's typology is there a place for the much-needed African identity development for black children (Akoto, 1992; Akoto \& Akoto, 1999, 2007; Hilliard, 1997, 2003; Shujaa, 1994). Murrell (2002) illustrated Africentric educationists concerns:
Multicultural education as it is applied to work with African American children [is problematic], namely, the detrimental influence that a pervasive diversity agenda has when it eclipses the critical identity work that undergirds powerful literacy learning for African American children. Knowing about diverse people and experiences should not supersede a child's own understanding of self and culture." (p. xxi)

Africentrics decry many conventional methods that are aimed at students of color. They are most critical of mainstream, Eurocentric education for black children because the ideas embedded within the curriculum pose as universal thinking laws or universal truths when Eurocentric ideas are, in fact, one-sided and specific to people of European descent (Akbar, 1984, 1992; Anderson, 2001; Asante, 1980, 1988; Brookins, 1984; Doughty, 1973; Hale-Benson, 1982; Hilliard, 1997; Lee, 1992; Lomotey, 1978; Madhubuti, 1973; Ridley, 1971). Examples of culturally specific parts of the curriculum that pose as universal truths include the Christopher Columbus story. Columbus did not discover the U.S. landmass for all groups of people, especially the natives (such as the Cherokee people) who were already there (Van Sertima, 1976). The existence of the Pythagorean theorem is also an example of such "universal" Eurocentric thinking, as Pythagoras was predated by hypotenuse theorists such as the African named Imhotep (James, 1976)—who is not recognized or discussed in U.S. public schools at all. Finally, Eurocentric education maintains the superiority of analytical thinking, but African American educational psychologists offer that African Americans are more relational in their thinking (Hale-Benson, 1982; Hilliard, 1997; Nobles, 1986). The Eurocentric educational system omits the roles of entire groups of people in mathematics and history and also ostensibly suggests that blacks should reorient their natural thinking processes. All of those factors affect African American achievement. Africentric educationists critique Eurocentric universalism and simultaneously attempt to correct the historical record by bringing the cultural accomplishments, folkways, and mores of Africans to the fore so that blacks (and others) can learn from those histories as well.

Although Africentric education is seen as a politically charged endeavor, it is actually no different from what most other groups do to educate their children. For example, Catholics engage students in Catholic-centered education by purporting the primacy of Catholicism, 
and Jewish-centered schools teach students that they should participate in the larger society but pledge primary allegiance to Jewish needs and causes. Hilliard (1997) reported similar activity among Asians and Latinos. African-centered education is similar, only instead of imbuing a sense of Catholic, Jewish, Asian, or Latino allegiance, it instills a sense of African allegiance.

A research study by Cherry and colleagues (1998) sought to explore the outcomes of Africentric education and philosophy on 5th and 6th graders. The results of their research indicate significant positive program effects on the young people who were exposed to Africentric education and philosophy. Also, research studies conducted on the Africentric approach have found positive effects on the general mental health of African American adolescent girls (Constantine, Alleyne, Wallace, \& Franklin-Jackson, 2006). Additionally, as in the case of Chick Elementary Charter School in Kansas City, Missouri, Africentric education has been used to take students from educational depression to educational excellence. Specifically, Teicher (2006) noted that "African American students at Chick see themselves as leaders, and their standardized test scores exceed the average for the state of Missouri" (p. 1).

\section{Africentric Education: General Africentric vs. Specific African}

It is important to note two different approaches used by Africentric leaders-the general Africentric and the specific African. Distinguishing these is important because there is now a shift away from general Africentric and toward specific African culture adoption. This change affects the ways African American children are taught about their identities. This move leads African Americans toward becoming familiar with their specific, indigenous African roots. General Africentric understandings, such as the need for black unity, self-determination, and community building, and the need for black children to become familiar with African value systems such as Maat (an ancient Nubian value system that is still practiced by some) are advanced by some scholars (Brookins, 1984; Doughty, 1973; Hilliard, 1997; Kunjufu, 1993; Lee, 1992; Lomotey, 1978; Madhubuti, 1973; Murrell, 2002; Ridley, 1971; Satterwhite, 1971). However, some Africentric educationists advance the need for black children to be exposed to specific African cultures (Afrik, 1981; Akoto, 1992; Akoto \& Akoto, 1999; Anwisye, 2006; Shujaa, 1994; Williams, 1987). In recent years, many of the more established Africentric schools (those in existence for more than 20 years) have begun moving away from general Africentric approaches and toward specific African cultural approaches. This means that Africentric education leaders are showing a general trend of moving away from "Africentric" practices (related to African) and toward using "African" practices (adopting the practices of a specific African group such as the Wolof people).

Many Africentric leaders use specific African cultural forms to inform the direction of their schools. However, they do not push any one African ethnic group over another because indigenous African cultural practices are actually quite similar from group to group. That is, the contents of Nguzo Saba (an East African-derived system consisting of seven major principles and values) and Maat are general enough that if one was not east African or Nubian, they could still recognize the systematic African cosmological and epistemological ontology within those principles. Furthermore, the Akan ethos and Onyame paradigm (a paradigm of thought used by the Akan that places God, or Onyame, at the center) are explicated in depth by Akoto \& Akoto (1999), and they harmonize perfectly with both Nguzo Saba and Maat. Furthermore, Fu-Kiau's illumination of the African Cosmology of the Bantu-Kongo people (1988) is in direct line with Nguzo Saba, Maat, and the Onyame paradigm. Lastly, the Igbo people's traditions (e.g., Dibia) of Nigeria (Umeh, 1997) virtually mirror the cosmological, axiological, and epistemological offerings of Nguzo Saba, Maat, Onyame, and those of the Bantu-Kongo.

\section{Research Methodology}

The complexity or novelty of Africentric ideas and understandings requires the collaboration of traditional research genres and less-traditional genres for research design. The design, implementation, and analysis of this research combine ethnography and Africalogy (Asante, 1990). The combination of both theoretical considerations is crucial because they seek to resolve intensely conflicting modes of research. That is, the traditional modes demand adherence to the developed and developing rituals of the qualitative discipline, and yet Africentric theorists demand methods that are "wholly consistent with the unique position of African Americans in American society" (Asante, 1990, p. 147). In this research I advocate for Africentric theory and also employ ethnographic methods for examining Africentric education practice.

Asante (1990) defined Africalogy as "The Africentric study of phenomena, events, ideas, and personalities related to Africa" (p. 14). Asante provided insight into 
the shape of the discipline of Africalogy:

Centrism, the groundedness of observation and behavior in one's own historical experiences, shapes the concepts, paradigms, theories, and methods of Africalogy. In this way Africalogy secures its place alongside other centric pluralisms without hierarchy and without seeking hegemony. As a discipline, Africalogy is sustained by a commitment to centering the study of African phenomena and events in the particular cultural voice of the composite African people. Furthermore, it opens the door for interpretations of reality based in evidence secured by reference to the African world voice. (p. 12)

Africalogy also requires that researchers become familiar with the phenomena being studied. Cultural and social immersion is preferred over scientific distance. Asante (1990) explained, "This [immersion] process in itself is extremely difficult because it means that the researcher must have some familiarity with the history, language, philosophy, and myths of the people under study" (p. 27). The Africalogical research genre requires that research be culturally relevant to the population being studied. This means that research should be wholly considerate of the "cultural frame of reference" (as coined by Ogbu, 1993) of those being researched. The Africalogical research genre holds that "One cannot study Africans in the U.S. or Brazil or Jamaica without some appreciation for the historical and cultural significance of Africa as source and origin" (Asante, 1998, p. 15). In this case, I was compelled to comprehend the culturo-ideological practices and understandings of leaders within the schools in order to understand the values and cultural transmission processes in Africentric schools. In other words, as Asante (1998) suggested, my first work was to competently understand the history, culture, and underlying philosophies of school leaders as a prerequisite to gaining any understanding of their work.

\section{Participants}

I chose four Africentric schools and their leaders for this study, ensuring that I included two different types of schools-private and public charter. National Africentric Private School (NAS), located in Washington, D.C., was selected as an appropriate locale because of its popularity among Africentric educationists as a model Africentric school in the United States. Participant observations and informal interviews with the founder, Baba Kojo, and other NAS leaders were conducted in classrooms, during meetings and conferences, during school rituals, and during a summer cultural experience called Nom. I conducted formal interviews with Baba Kojo and various other participants at NAS. Baba Kojo has participated in NAS leadership for nearly 30 years. Herufada Private School (HPS) is also one of the most popular Africentric schools in the nation and is located in St. Louis, Missouri. HPS's leader, Baba San, (meaning, "father figure" San) is popularly known for being committed and consistent in the community and serves as one of the lead trainers of teachers who are new to Africentric schools. Baba San has been the leader of HPS for 25 years. The two public charter schools, Rising Sol Elementary (RSE) and New School Elementary (NSE), are both located in Washington, D.C. and are different from NAS and HPS in that they are public charter schools. RSE's leader, Ms. Brenda Boykin, has led Africentric schools for more than 30 years. Mama Maya, the leader of NSE, just recently began her tenure in that position. Although I had a limited number of institutions to choose from, I identified these four educators because they represent leadership in two different types of schools (private and public charter). All of the leaders interviewed are trusted and are seen as very important members of the communities they serve.

\section{Data Collection}

Data from interviews were retrieved as part of an ongoing study over a four-year time period (2002-2006) by means of classroom observations, attending Africentric education meetings and conventions (such as the annual Return and Retrieve the Culture Conference at NAS, the Council of Independent Black Institutions Conference, and the Africentric Education Leadership Roundtable), participating in Africentric leadership meetings (the Ndundu), formal and informal interviews of the leaders themselves and of their faculty and staff members, participation in African rituals and events (such as the annual Nom cultural event in Virginia and African cultural festivals), and joining a community collective at NSE Africentric School. Data were secured in an electronic notebook, audio interviews, and visual productions. The computer program Ethnograph Version 5.0 was used to assist with coding and data management. All of the school leaders signed an inform consent acknowledgement. 


\section{The Leaders Speak: Toward Understanding the Goals of Africentric Education}

Leaders in Africentric schools tend to be seasoned teachers and administrators with long careers in the field of education. Baba Kojo, Baba San, and Ms. Boykin have each individually worked in the field of education for nearly 30 years. All three founded their schools because they wanted to create an appropriate place to send their own birth children. When these Africentric schools began in the 1970s, these parents taught some of their own children. Baba Kojo explained, "We saw appropriate schooling as schooling that placed the needs and interests of black people at the center of the school's purpose." Even though Ms. Boykin has been principal of RSE public charter school for only 7 years, she founded an Africentric private school where she served as principal for 30 years. That private school still stands; however, she is no longer principal of that institution. The principal of NSE, Mama Maya, has been a teacher and principal in the public school system for 9 years. She served as principal of a traditional, non-Africentric school in D.C. for two years prior to serving as principal and cofounder of NSE during the academic year 2006-2007.

Baba Kojo, Baba San, and Ms. Boykin were all part of the 1960s human rights movements. Baba San explained, "Although our struggle particularly is part of the human rights struggle for sovereignty, we were motivated by the '60s civil rights movement." Popularly known black activists such as Kwame Ture, Frantz Fanon, and others that came out of the black power movement at Howard University and other university campuses influenced Baba Kojo, Baba San, and Ms. Boykin. Although the civil rights movement influenced these leaders, Baba Kojo explained that "we were not interested in using the top-down, staunch, male-centered leadership style of the movement." There were also debates among these young leaders about what the ideological focus of the community should be. Ms. Boykin explained that even though the people who eventually started Africentric schools did not all know each other at the time, they saw themselves as having the ability to make a great impact within their community. Baba Kojo was part of a core group called NAS Leaders who were parents interested in finding appropriate educational venues for their own children. They went back and forth about ideological focus for years and finally agreed that the school should have a nationalist focus with an emphasis on black sovereignty. The group members wanted to draw on African traditions to assist with focusing their vision.
HPS and RSE were started in much the same way that NAS was-groups of young black college students wished to figure out how they were going to come together ideologically so that they could teach their own children, and later children in the community. The leaders of HPS took the same ideological bent as those of NAS - focus on black sovereignty and independence. These school leaders leaned more toward black sovereignty than civil rights because as Baba San explained, "Many of the decisions that the civil rights leaders were making seemed to concern "whether they wanted to have comfort now or freedom later." He continued, "They seemed to often choose comfort now." HPS and NAS started off as institutions that were geared toward sovereignty and independence; however, the leadership within RSE focused more on broader goals related to African identity development.

Unlike all of the other schools, NSE is a new Africentric school, founded in 2006. However, similar to the others, NSE's cofounder serves as principal of the school. Situated east of the Anacostia river in D.C. and located in one of the most socioeconomically challenged areas of the nation's capital, NSE was started in order to fulfill the goals of the '60s movement. According to its founders, the school is important within the community because an institution was needed that would prepare students to become responsible and productive members of the community. NSE's founders believe that black children suffer in U.S. public schools because they do not receive an education that is relevant to them. When asked why there was still a need for NSE considering its predecessors (such as NAS), Mama Moro explained that "the schools that were like NSE that came before paved the way for us, but the students have changed, and the communities they come from have changed." Baba Kojo, Ms. Boykin, and Mama Maya all spoke much about the degree to which the black community in D.C. has changed, as did Baba San regarding St. Louis.

\section{Changing Black Communities: More Avariciousness, Less Unity}

I asked all of the leaders about change in the black community. All of them told stories of black communities they grew up in having less illness and disease (e.g., HIV, hypertension, and diabetes were all mentioned by all of the participants). They mentioned that there were more positive black male role models, and there was higher community morale. Baba Kojo explained that some of the losses were a result of miscalculations:

A shortcoming of the civil rights movement was that we lost the community. [That] movement 
did not necessarily facilitate the loss of family; it was the leadership. Too much of the national leadership found themselves and their energies being manipulated and channeled. The goals of the people were simple: freedom from terror, economic betterment, etc. Integration, however, as a strategy was adverse to that, and electoral politics were adverse to that. Instead of community building, [things like] voter registration and movement to middle class status took the elite out of our communities and took their efforts toward the mainstream. They decapitated the community. Then, highways went straight through the black community. When the interstates came through, all of the establishments were lost-the economic heart of the community was ripped out. That was a strategic error on the part of the national leadership due to an incomplete assessment-I would never doubt the integrity of Martin Luther King, but that was a miscalculation.

Africentric leaders are concerned that as the black community continues to move further away from core cultural principles such as unity and self-determination (which they believe have African roots), the community will experience more illness and lower morale. Ms. Boykin, Baba Kojo, and Baba San believe that not enough parents and other community members have made a decision to try to maintain a sense of unity and togetherness in the community, so these educators have decided to exert most of their energy on working with those parents and community members who are already focused that way. Mama Maya and the leadership staff at NSE have a slightly different perspective. They also believe that there are not enough families and community members who are concerned about communal unity, yet they see the development of their community as part of the reason for their existence. Mama Maya explained:

[NSE] was developed because of our commitment to this community. The members of this community see a need for kids who are responsible and productive. We want to help create students who are leaders and have the confidence and skills to help improve their own communities. Our approach extends beyond school walls. There is a lot of violence and apathy in this community [and we] can't survive like that. As Baba Kojo alluded to, Africentric education leaders are worried because many of the blacks who once were concerned about black community development in the most downtrodden areas have now relocated. One of NSE's cofounders, Mama Moro, spends much time trying to persuade those who have left to relocate back to D.C.'s most challenged areas. Mama Moro explained, "Many of them left D.C. feeling disillusioned about the future and turned to the suburbs where they can have more comfortable and easier lives. But now the community and the kids are suffering because the people with the most [ability to acquire] resources now do not live anywhere around here." Mama Moro's concerns of brain and resource drain mirror Baba San's warnings about choosing comfort now over freedom later-eventually the problems of the inner city will find their way to the suburbs.

The leaders believe that regardless of more popular viewpoints on cultural affiliation (that people belong to many different "cultures" during their lifetimes, not just their ethnic culture), members of the black community are only putting in arrears what eventually must be accounted for-the miseducation of their children and the chaos and lack of social cohesion within their communities. Baba Kojo believes that the sense of order and cohesion are based on simple factors, as he recounted:

When my family moved to Atlanta, it was still a strong sense of community. Folks had a sense to go to college and come back. We were among the last of those that experienced that wholeness of a connected black community. Every black person you met on the road back then, you waved at them-gleefully. Simply because you were black. Things were not simpler, but they were a lot clearer. A sense of accountability was there. I remember having to walk a couple of miles to school. I remember cursing one day, and a lady said, "I'm gonna tell your grandmother."

Even though RSE and NSE are newer institutions, they send their teachers to Africentric teacher training institutes that were founded by Baba San and Baba Kojo (administrators also often attend the Africentric teacher training institutes). The focus of the training institutes mirrors Baba Kojo's and Baba San's current philosophical orientations toward specific cultural reattachment. For example, when asked about the main substance of the teacher training institutes, Baba Kojo commented that the most important part of teacher training "is that the teachers begin to understand the importance of the nation building concept. When our students are taught by instructors who are not dedicated to that concept, they create more confusion in their lack of direction, and 
as a consequence the children too become the pawns and playthings of those who are directed and powerful."

Although I was concerned that it would be difficult to observe nation building among Africentric leaders, understanding the difference between specific cultural practice and general Africentric practice made such observation possible. That is, the practices of the school are understood as nation building in progress, but such a revelation is made only by looking at the school in the ways that the leaders look at their schools. In the past, Africentric education leaders saw the schools as general Africentric institutions where families who are interested in returning to African traditions could be assured that their children would be nurtured accordingly. Nurturance toward general Africentric practice most importantly includes transmitting to children the value of taking agency over themselves and their communities. For Africentric education leaders, such agency is, in part, nation building in progress. The transmission process takes place by involving the students in practices such as the Council of Independent Black Institutions (CIBI) Science Fair, certain portions of the Return and Retrieve the Culture Conference, and some rituals. Transmission is cultural; therefore, it undergirds everything that occurs within these schools. The transmission of culture occurs via people simply practicing their cultures and interacting with each other.

\section{When Culture and Education Meet}

Although most Africentric schools still tend to use general Africentric approaches, leaders of many highly regarded institutions are beginning to focus more on specific African cultural reattachments. Leaders are now studying with what they call "traditionalists." Traditionalists are usually people who live in Africa and serve as keepers of pre-colonial African traditions, such as Yoruba. Yoruba is a way of life that is practiced mostly within Nigeria. Baba Kojo explained how leaders at his school moved toward the Yoruba tradition:

[We] studied with these practitioners in New York. They have been organizing in this way since the '50s to establish traditional culture, and they had the oldest traditional dance group in the country-using Yoruba in Nigeria. They had a branch in New York. We went to some of their programs in the city and were impressed with their work here and abroad. This is how Yoruba became the cultural theme of the school. We don't advertise that Yoruba is the cultural theme of the school; Yoruba informs the cultural direction of the school—we don't try to sell that to parents, etc. Our principal motivating factor was the establishment of families. The people in New York help us with, you know, some of the cultural issues.

NAS's Yoruba cultural focus is a result of the leaders' interactions with these practitioners. Baba San is involved in understanding the Akan culture (which is practiced in Ghana), and he and the leadership of HPS use that tradition to inform the direction of their school. Although they are studying different traditions, Baba San and Baba Kojo work closely together to help teachers and practitioners understand how indigenous African culture can be used to increase black children's educational potential. Ms. Boykin is not tied to Yoruba or Akan cultural paradigms, but she explained that she "recently began to look into the Swahili rituals. Even though many of us are scared to go that way, we have to understand that's where we came from." Furthermore, teachers within her school (RSE) attend the training institutions where they are learning the importance and methods of being informed by indigenous African cultural ethos from leaders such as Baba San and Baba Kojo.

At NSE, Mama Maya has also hired traditionalists to help inform her teachers. In the past, charter schools have used African cultural information to tether in different practical ways have used varied types of African cultural information together in practical ways. Mama Maya noted that she and other NSE leaders believe that, "It is important for our teachers to understand that it's not about them finding resources to teach 'cultural stuff.' Instead, we want them to know how important the concept of being African is, and we need to know that being African means practicing African culture."

Africentric school leaders believe that the most important manifestation of culture is the existence of a functioning and productive family. Baba San explained: "The most important institution in our community is the family. No other institution has stood longer [and] no institution in the future will prove more beneficial to our continued existence." The leadership cadres within Africentric schools believe that family involvement happens in specific cultural ways. Families have certain responsibilities within the school. For example, on family night the family members do not simply show upthey are responsible for sharing with others some of the successful aspects of their family's ways of functioning. For example at NAS, Imani's parents discussed how they managed their time with their three daughters, even 
though Imani's mom worked the day shift and her dad worked the night shift. Other families listened and asked questions about how they could keep their family functioning effectively considering the limitations caused by time and work. The discussion opened, and whenever someone spoke they articulated their family's struggles and triumphs, not their individual issues.

During classes, students are reminded that teachers have close contact with their parents. Mama Maya said to a student, "You did a good job helping your grandmother last night in the yard; now can you simply sit still in this circle?" Comments like this one help create seamless relationships between home and school for the children. An example of the close relationship between staff and students is that teachers regularly teach class while carrying troubled pre-K students on their hips. A family atmosphere is created as teachers sometimes (during class) ask older students to help with the younger ones. Once, Mama Maya said to a 6th grade student, "take him [a pre-K student] to the restroom and help him do his business." It is evident that most of the staff members choose to engage intimately as opposed to distantly with students, and they see their relationships with students in "mother/father" with "son/daughter" ways, not "teacher/administrator" vs. "student/clientele."

\section{Conclusions}

In recent years, attendance has nearly doubled at the NAS Return and Retrieve the Culture Conference, and the Nom ReAfricanization Cultural Experience has tripled its membership since 2002. Both RSE and NSE now have waiting lists of parents wishing to enroll their students, and HPS is at capacity enrollment. Furthermore, other Africentric schools such as Chick Elementary in Kansas City, Missouri; Sankofa Shule in Lansing, Michigan; and Marcus Garvey School in Los Angeles are all experiencing national support and in some cases unprecedented success. An example of the success of Africentric schools is that all of the schools that were part of this study have 100 percent African American students, and all of them that have scores to report are meeting or surpassing district standards. Considering that many black students in urban districts throughout the United States do not meet state academic standards, the effective practices and strategies of Africentric schools should be further investigated. However, it is important to note that, according to these leaders, their effective practices and strategies are embedded in culture and philosophy, not resources or pedagogy.
Major educational challenges faced by black children and communities have shaped the current interest in culturally centered education in the United States. Africentric education leaders are working to restore a sense of self-help and cultural renewal to black communities, but they do so under difficult conditions-namely aggression toward such efforts coming from the majority and a lack of support from blacks themselves. Even though the practices of Africentric education leaders do not receive much attention from mainstream researchers, the work they do is seen as being crucial to concerned members of the black community who have educated themselves to the point of understanding the comprehensiveness of the approach. Surely it is quite possible that any interest in Africentric education is driven by the deep desires of proponents to find meaningful ways to address the major problems that continue to harm that community. Africentric educators believe that an overhauled and African-centered educational system can be a major vehicle for the necessary community change. Focusing on the contemporary issues in education (such as low math and reading scores or the achievement gap) may be a necessary task, but resolving those issues alone provides at best a quick fix for problems that do not have their origin in the field of education at all. The problems faced by black children and communities are steeped in decades of intentional and unintentional ignorance about, and aggression toward, supporting efforts that might empower blacks with agency and self-determination over their own communities.

From the work of Africentric educationists we can gain much insight into what specific systematic inclusions might help empower blacks to assume agency over themselves and their communities through education. Akoto and Akoto (1999) explicated three important broad and overlapping phases that provide the basis for major change in the education of black children. Those phases are rediscovery, redefinition, and revitalization. They explained, "During the rediscovery phase the person reconstructs the full history of the African world within an African-centered framework" (p. 9). The redefinition phase involves the following:

Development of a comprehensive and thorough analysis of Africa's historic enemies in both internal and external manifestations, an elaboration of a comprehensive and detailed theory of Africa's spiritual/material continuum, the development of an ideological tract that is concise in its objectives and principles, the reestablishment of appropriate moral codes and standards, the 
abandonment of non-African cultural formations, and an attempt to ground oneself in the communitarian traditions of Africa. (p. 10)

The last phase, revitalization, involves the "encouragement and facilitation of appropriate action on regional, national, and international levels" (p. 10). These three phases can serve as part and parcel of the necessary policy changes.

\section{Policy Recommendations}

Considering the circumstances in which black children and communities find themselves, many black scholars and activists such as Hilliard (1997) and Kunjufu (2001) have called for the U.S. Department of Education to declare a state of emergency regarding the education of black children. Upon such a declaration, the following policy recommendations may help change the existing realities:

1. Include African-centered theories and philosophies as part of undergraduate teacher education programs.

2. Incorporate Akoto and Akoto's (1999) three phases of re-Africanization as part of the education of students, especially within schools where African Americans predominate.

3. At the district level, charge schools with providing an education for black children that incorporates information and knowledge on the following imperatives: (a) their African identity, (b) pan-Africanism, (c) African cultures and values systems, (d) black nationalism, (e) community control/institution building, and (f) educating as opposed to "schooling" black students. (For a more detailed discussion on these imperatives, see Shockley, 2007).

If presented in an African-centered way, the inclusion of these policy recommendations revolutionizes the current disconnected ways that black children are taught. By engaging black children in a full rediscovery and redefinition of themselves as African people and then charging them to revitalize the African world, we put them on the pathway toward self-help. In the ways that other groups use history and heritage (e.g., Western civilization, Columbus Day, and Jamestown, Virginia, commemorations) to rediscover, redefine, and revitalize themselves, Africentric educationists argue that black children need the same.

\section{References}

Afrik, H. T. (1981). Institutional development: The need for black educational models and is the community control of schools still alive? Chicago: Black Spear Press.

Akbar, N. (1984). From miseducation to education. Jersey City, NJ: New Mind.

Akbar, N. (1992). Chains and images of psychological slavery. Jersey City, NJ: New Mind.

Akoto, K. A. (1992). Nationbuilding: Theory and practice in Afrikan-centered education. Washington, DC: Pan Afrikan World Institute.

Akoto, K. A., \& Akoto, A. N. (1999). The Sankofa movement. Washington, DC: Oyoko Infocom.

Akoto, K. A., \& Akoto, A. N. (2007). Maroonage: Issues in building and sustaining independent community. Sankofa, 5-17.

Anderson, C. (1994). Black labor, white wealth: The search for economic justice in America. Bethesda, MD: Powernomics.

Anderson, C. (2001). Powernomics: National plan to empower black America. Bethesda, MD: Powernomics.

Anderson, M. (2005). Pre k Black kids getting expelled at alarming rates. Baltimore Times Online. Retrieved February 22, 2008 from: http://www.btimes.com/News/article/article.asp?Ne wsID $=4261 \& s I D=3$

Anwisye, S. (2006). Ancient or postmodern values: Revisiting the old African ways. Sankofa, 41-51.

Appiah, K. A. (1993). Europe upside down: The fallacies of Afrocentricity. Sapina, 5(3), 2-7.

Asante, M. K. (1980). Afrocentricity. Trenton, NJ: Africa World Press.

Asante, M. K. (1988). The Afrocentric idea. Philadelphia: Temple University Press.

Asante, M. K. (1990). Kemet, Afrocentricity, and knowledge. Trenton, NJ: Africa World Press.

Asante, M. K. (1991). The Afrocentric idea in education. Journal of Negro Education, 60(2), 170-180.

Asante, M. K. (1998). The Afrocentric idea. Philadelphia: Temple University Press.

Banks, J. A. (2001). Cultural diversity and education: Foundations, curriculum, and teaching. Boston: Allyn \& Bacon.

Brookins, C. C. (1984). A descriptive analysis of ten independent black educational models. Master of arts thesis, Michigan State University, Ann Arbor, MI. 
Cherry, V., Belgrave, F., Jones, W., Kennon, K., Gray, F., \& Phillips, F. (1998). NTU: An Africentric approach to substance abuse prevention among African American youth, The Journal of Primary Prevention, 18(3), 319-339.

Constantine, M., Alleyne, V., Wallace, B., \& FranklinJackson, D. (2006). Africentric cultural values: Their relation to positive mental health in African American adolescent girls. Journal of Black Psychology, 32(2), 141-154.

Delpit, L. (2001). Other people's children. New York: The New Press.

Doughty, J. J. (1973). A historical analysis of black education-focusing on the contemporary independent black school movement. Doctoral dissertation, Ohio State University, Columbus, $\mathrm{OH}$.

Fu-Kiau, K. (1988). African cosmology of the BantuKongo. Imprint Editions: Baltimore

Hale-Benson, J. (1982). Black children: Their roots, culture, and learning styles. Baltimore: Johns Hopkins University Press.

Hilliard, A. (1997). SBA: Reawakening of the African mind. Gainesville, FL: Makare.

Hilliard, A. (2003). No mystery: Closing the achievement gap. In T. Perry, C. Stelle, \& A. Hilliard (Eds.), Young, gifted and black: Promoting high achievement among African American students (pp. 131-165). Boston: Beacon.

Howe, S. (1998). Afrocentrism. Oxford: Oxford University Press.

James, G. G. M. (1976). Stolen legacy. San Francisco: Julian Richardson.

King, J. (2005). Black education: A transformative research and action agenda for the new century. Washington, DC: American Educational Research Association.

Kunjufu, J. (1993). Hip hop vs. Maat: A psychosocial analysis of values. Chicago: African American Images.

Kunjufu, J. (2001). State of emergency: We must save African American males. Chicago: African American Images.

Lee, C. D. (1992). Profile of an independent black institution: African-centered education at work. Journal of Negro Education, 61(2), 160-177.

Lefkowitz, M. (1996). Not out of Africa. New York: Basic Books.
Lomotey, K. (1978). Alternative educational institutions: Concentration on independent black educational institutions. Master of education thesis, Cleveland State University, Cleveland, $\mathrm{OH}$.

Lomotey, K. (1992). Independent black institutions: African-centered education models. Journal of Negro Education, 61(4), 455-462.

Madhubuti, H. (1973). From plan to planet: The need for Afrikan minds and institutions. Chicago: Third World Press.

Madhubuti, H. (1978). The clash of races. Chicago: Third World Press.

Madhubuti, H. (1990). Black men, obsolete, single, dangerous? The Afrikan American family in transition. Chicago: Third World Press.

Murrell, P. C. (2002). African-centered pedagogy: Developing schools of achievement for African American children. New York: State University of New York Press.

National Center for Education Statistics (NCES). (2004). Digest of education statistics. Retrieved February 11, 2006, from www.nces.ed.gov/programs/digest

Nobles, W. (1986). African psychology: Toward its reclamation, reascension, and revitalization. Oakland, CA: A Black Family Institute.

Ogbu, J. (1993). Differences in cultural frame of reference. International Journal of Behavioral Development, 16(3), 483-506.

Ridley, J. A. (1971). The independent black (educational) institution: An exploratory study with implications for the institutionalization of American schools. Doctoral thesis, University of Michigan.

Rivers, F. (1998). African mathematical genius giri so. Lansing, MI: Sankofa.

Rivers, F. (1999). African mathematical genius benne so book 2. Lansing, MI: Sankofa.

Rivers, F. (2000). African mathematical genius bolo so book 3. Lansing, MI. Sankofa.

Rivers, F. (2001). Potential genius. Lansing, MI: Sankofa.

Satterwhite, F. J. (Ed.). (1971). Planning an independent black educational institution. New York: Afram.

Schlesinger, A. (1992). The disuniting of America. New York: Norton.

Shockley, K. (2007). Literatures and definitions: Toward understanding Africentric education. Journal of Negro Education, 76(2), 103-117. 
Shujaa, M. J. (Ed.). (1994). Too much schooling, too little education: A paradox of black life in white societies. Trenton, NJ: Africa World Press.

Stedman, L. (1997). International achievement differences. Educational Researcher, 26(3), 4-15.

Teicher, S. (2006, June 8). An African-centered success story. Christian Science Monitor, 98(35), 14.

Tharp, R. G., \& Gallimore, R. (1991). Rousing minds to life: Teaching, learning, and schooling in social context. New York: Cambridge University Press.

Thompson, B. (1994). African-centered interdisciplinary multi-level hands-on science: Preprimary-8th grade. Washington, DC: Roots Activity Learning Center.

Thompson, B. (1998). Black madonnas and young lions: A rites of passage for U.S. African adolescents.

Washington, DC: Roots Activity Learning Center.

Umeh, J. A. (1997). After God is dibia. London: Karnak.

Van Sertima, I. (1976). They came before Columbus: The African presence in ancient America. New York: Random House.

Williams, C. (1987). The destruction of black civilization. Chicago: Third World Press.

Woodson, C. G. (1933). Mis-education of the Negro. Washington, DC: Associated Publishers, Africana Research Publications.

\section{End Notes}

1 The words Afrocentric, Africentric, and African-centered are used interchangeably in this article.

IJEPL is a joint publication of the Association for Supervision and Curriculum Development, the Faculty of Education at Simon Fraser University, and the College of Education and Human Development at George Mason University. By virtue of their appearance in this open access journal, articles are free to use, with proper attribution, in educational and other non-commercial settings 90 days after initial publication. Copyright for articles published in IJEPL is retained by the authors. More information is available on the IJEPL Web site: http://www.ijepl.org 